\section{IP periodica polytechnica}

\author{
Architecture \\ 43/2(2012)53-56 \\ doi:10.3311/PPar.7288
}

http://www.periodicapolytechnica.org/ar

Creative Commons Attribution (i)

RESEARCH ARTICLE

\title{
Life in the Pauline Monasteries of Late Medieval Hungary
}

Beatrix F. Romhányi

RECEIVED 15 DeCEMber 2012

\begin{abstract}
The Pauline order emerged in the second half of the thirteenth century and became one of the most popular religious communities of medieval Hungary. Due to their mixed - hermitic, monastic and mendicant - character, their monasteries developed an economic system and a social network that was unique in the fifteenth and sixteenth-century kingdom. Their repudiation of higher education was coupled with the prestige of manual work and literary creativity. The main supporters of the order were members of the lesser nobility and the aristocracy.
\end{abstract}

\section{Keywords}

Pauline order · Middle Ages · everyday life · Hungary
Beatrix F. Romhányi

Károli Gáspár Calvinist University, Budapest, Hungary e-mail: t.romhanyi@gmail.com
Research on the Pauline order has always been a popular topic in Hungarian historiography between both professional and a large number of amateur researchers. Aside from the latter aspect, historians, archaeologists, art historians, literary historians and even architects such as the commemorated Tamás Guzsik have dealt with it since the beginning of the twentieth century up to the present. Although a seemingly complete history of the order could be written based on the sixteenth-century historical work of Gregorius Gyöngyösi, the number of reliable written sources has only developed from the second half of the fourteenth century; many aspects of the early history of the order still remain unclear. Archaeological evidence is also primarily available for the late medieval period.

Besides the charters, published or unpublished, already available on the web,[23] we have four documents of primary importance concerning the late medieval history of the Pauline order:

- the inventory of the medieval charters compiled by the Prior General Gregorius Gyöngyösi in the 1520s (published only partially in the volumes of Documenta Artis Paulinorum [1])

- Gyöngyösi’s historical work Vitae fratrum $[9,19]$

- the Miracula of Valentinus Hadnagy (also Prior General in the 1530s) [17]

- the Formularium maius, used by the secretary of the Prior General from the 1530s.[7]

From these texts and a range of archaeological evidence, gained from a relatively large number of excavations, compared to other religious orders in medieval Hungary, we now have quite a full picture of the life of the Pauline monasteries, their buildings, estates and their life.

The order, which emerged in the second half of the thirteenth century and received papal approval in 1308, became one of the most significant monastic communities of the late medieval Hungarian Kingdom. Supported mainly by the lesser nobility, the king, and after about 1380, by the aristocracy, the order became a religious community of mixed character: monastic, hermitic and mendicant traditions can all be detected in it. 
The Pauline monasteries were rather small, some of them being hermitages with four to six monks. The average number of a religious community was about ten, and only Saint Lawrence's monastery, where the central administration of the order resided, had a larger convent of about 30-40 individuals. According to the written and archaeological sources, the Paulines lived around 1500 in some seventy monasteries in Hungary, with a further twenty-five houses in Dalmatia, Silesia, Poland, Austria and Germany (mainly in Bavaria). Thus, the centre strongly gravitated towards Hungary throughout the Middle Ages. Although the Paulines lived in a large number of monasteries in Hungary, only the Franciscans had more friaries by the end of the fifteenth century, the number of the friars was not that high; we can realistically assume about 5-600 companions. Many of them, especially those taking part in the leadership and the management of the order, had, by the end of the Middle Ages, originated from market towns [12].

Since the order was founded in Hungary and its Prior General lived in Saint Lawrence's Monastery near Buda, the Paulines had a special status among the religious orders in Hungary, playing also a political role. Even their papal approval was connected to political events in 1308, namely the acknowledgement of Charles Robert of Anjou as King of Hungary (13011342). The order received royal support from his son, King Louis I (1342-1382), who purchased the relics of Saint Paul the Hermit from Venice in 1381 and remitted them to the central monastery of Saint Lawrence. The first flourishing period of the order began in the last third of the fourteenth century when its first monasteries outside Hungary (Senj - Dalmatia; Częstochowa, Miechów - Silesia) also appeared.

In the last decades of the fourteenth century, the social network of the order changed considerably, which also resulted in the transformation of its estate structure. High ranking aristocrats such as the Palatine Nicolaus Kont and his sons, or the Cudar family, supported Pauline monasteries by donating them urban houses in Buda. Although only a few houses remained in the possession of the friars over the long term, this event left its traces on the economy of the order. Several Pauline monasteries also received urban houses in other towns, in order to commercialize their production, mainly their wine (e.g. the monastery of Remete in Zagreb).[2, pp. 51-52] Another purpose of these houses was to receive rents. Parallel to this, landed estates such as vineyards, and also mills, were exploited through renting. The money received by the monks was then lent at rates. Their partners were usually local nobles, but even included the cities of Buda and Vienna. As a result of this pattern, the economy of the monasteries and the order as a whole shifted towards the financially based, "capitalistic" management [2, p. 138][4, p. 197].

The order seems to have had a relatively accurate record of the size and the structure of the needed possessions. This is indicated in a story told by Gyöngyösi in chapter 27 of Vitae fratrum, according to which the first prior of the Nosztre monastery refused the too generous donation of King Louis I, saying that the excessive wealth would encumber the friars to enter through the narrow gate (cf. Mt 7,13).[9, c. 27].

A second flourishing period can be connected to the reign of King Mathias Corvinus (1458-1490), whose sympathy towards the order was also recorded in the Vitae fratrum. Besides the spiritual aspects of this relationship, some of the leaders of the order, especially the Prior General Gregorius, influenced the King politically in the 1470s and 1480s.[16] There are several hints that King Mathias regarded the Pauline order as part of the sacral representation of the kingdom. Several of the foundations of these decades can be explained as expressions of loyalty (Szalónak [Stadtschlaining], Baumgarten, Monyorókerék [Girm], Sopron-Bondorf) or alliance (Wiener Neustadt). [6] The order also participated in the ecclesiastic reforms of the King and his successor King Wladislaus II Jagellon (14901516), taking over some monasteries from other orders (Szentjobb, Visegrád - Benedictine; Csút, Váradhegyfok, Zsámbék - Premonstratensian).[1, passim][5, passim] The royal support continued until the cessation of the medieval Hungarian state: both King Louis II (1516-1526) and King John Szapolyai (1526-1540) continued to favour the Paulines; the former even brought the skull of Saint Paul the Hermit from Prague for them (1523).[9, c. 87].

Due to the mixed character of the order, referred to previously, the German historian Kaspar Elm called it an unmade mendicant order. Although the Paulines had landed estates from the beginning, they managed them in an innovative way as the incomes apparently did not cover the expenses. Therefore, they stood in need of the different forms of alms. The first donation of this type can be connected to King Louis I, who gave the order a yearly rent of salt to the value of 300 florins. His donation was subsequently confirmed by the King's successors, and the rent is even mentioned in the Formularium maius [2, pp. 120-121].

Other types of alms such as the testaments, the pro anima donations and the indulgences were also present.[2] The first two categories are nevertheless somewhat problematic, since, in certain cases, it is hard to decide whether the matter is a real donation or rather a business affair [2, p. 126]. Namely, in some cases we read that the donator gave a certain estate partly for the salvation of his (his family's) soul and partly for a given sum he received from the friars. However, a large or even the major part of these charters contains alms as donations.

The indulgences represent a particular form of alms collecting. Due to the popularity of the order, several Pauline monasteries became attractive pilgrimage places. The most famous were beside the tomb of Saint Paul in the monastery of Saint Lawrence near Buda, the churches of Lepoglava (today in Croatia) and Máriavölgy/Marienthal (today Marianka in Slovakia). The central administration of the order gradually gained control over these sites in order to avoid unwanted 
concurrence between them.[21] As a result, the recurrent occasions of the outdoor fairs assured a regular income for the friars. The reputation of the main Pauline place of pilgrimage, the Saint Lawrence's monastery, is reflected in the booklet written by Valentinus Hadnagy about the miracles that happened at Saint Paul's tomb.[17] Many pilgrims came from remote places of the Kingdom such as the counties of Baranya, Csanád, Somogy or Zemplén, and even from Croatia and Transylvania, demonstrating that the site was known country-wide.[11, p. 107] Another aspect of the question is the pastoral care the friars participated in: it was the logical consequence of running pilgrimage sites, but also an opportunity to attract more people. The privileges granted the order, for example, that their confessors were allowed to absolve believers from reserved sins, also helped to maintain their appeal.

Finally, the alms strictly meant, should be mentioned. There are two sources referring to the methods of alms collection. The first is the account book of Prince Sigismund Jagellon (later King Sigismund I the Old [1506-1548]) who spent altogether nearly three years with his elder brother, King Wladislaus II of Hungary, in Buda between 1500-1505. According to his accounts, he regularly gave alms to different mendicant communities and to the Paulines. The latter usually offered the Prince some fruit (apples, peaches, nuts, pears) - obviously produced by themselves - and received alms between 25 denarios and 1 florin.[22]

Another possibility for alms collection was to present a formal request (supplicatio). These texts appear in many variations in the Formularium maius [7]. The addressee could be the Emperor, the King, the Queen, an Archbishop, etc. The supplications do not usually contain any special demand; rather they are a sort of complimentary gesture.

As far as the intellectual and spiritual life of the friars is concerned, it should be noted that the order did not support the higher education of its members. Although we can find a number of learned persons, especially clerics, in the administration of the order, e.g. the former Bishop of Csanád Johannes Szokoli, the former suffragan Bishop of Transylvania Dyonisius of Gyalu or the former Canon of Várad Michael (all of them mentioned in Vitae fratrum), they were all learned before they entered the order. The spirituality of the order did not favour scholarly work in general. Instead, there were renowned artisans and artists. Gyöngyösi enumerated some of them in the central monastery of the order (e.g., fr. Valentine baker, fr. Paul waffle-maker, fr. Sebastian tailor among the craftsmen, the poet fr. Albertus Csanádi, the organists fr. Johannes, fr. Johannes of Kesztölc, fr. Colomanus, fr. Servatius among the artists).[9, passim] The proportion of these friars seems to have been relatively high in the order, although it was still lower than in the observant vicariate of the Franciscans. With regard to the lay brothers, there are limited sources; we have just a few lists of friars and they contain mainly the senior members of the convents. Lay brothers occur very rarely in the charters, the only source mentioning them in a larger number is Gyöngyösi himself, and even he spoke only about the most notable fraters conversi.

We also have to point to the literary activity of some of the friars. Fr. Albertus Csanádi, fr. Gregorius Gyöngyösi and fr. Valentinus Hadnagy have already been mentioned, but one should not forget some of the other authors, such as fr. Vincentius Fekete who wrote some ascetic works, or fr. Thomas Szombathelyi who commented on the rule. Both of them were in place of the Prior General in the second half of the fifteenth century.[9, c. 54, c. 64] They were authors of diverse, mainly spiritual and mystic works, although, most of them were lost. Some evidence of the official literacy and the liturgy survived $[18,20]$. It is also worth mentioning that some of the most important works had already been printed in the early sixteenth century: Gyöngyösi's Vitae fratrum in Rome, Hadnagy's booklet on the miracles of Saint Paul in Venice [18].

Despite the intensive literary life within the order, we cannot find the well-known works of the Devotio moderna in the Pauline libraries.[13] While the Paulines propagated the spirituality of this movement,[15] the lecture of Kempis's work cannot be proven, and it is probably not by chance that there was no Hungarian translation of the Imitatio Christi in the Middle Ages or in Early Modernity. Of course, this was not only the "fault" of the Paulines since other orders, especially the observant Franciscans also spread the ideals of the movement - without actually spreading its literature.

Lastly, there was large-scale building activity in several monasteries at the end of the fifteenth and the beginning of the sixteenth century. This feature is of course connected to the late medieval flourishing period of the order, mentioned at the beginning of this paper. The central monastery of Saint Lawrence, the monasteries of Fugyi (today Fughiu, Romania), Szentkereszt (Kesztölc), Visegrád and Zsámbék, as well as the church of Fehéregyháza (Budapest II), were rebuilt, and new monasteries emerged in Nagyvázsony, in Bondorf near Sopron or in Tokaj.[8, passim] Some of these monuments such as the Saint Lawrence's or the Nagyvázsony monastery, were buildings of exceptionally high quality. The building works were financed by the patrons, another common feature with the mendicant orders, which reflected the popularity of the order.

Connected to the constructions, works of art were also prepared, some of which were made by members of the order. The main source is again Gyöngyösi. He mentioned two sculptors or stone-carvers, fr. Dyonisius and fr. Vincentius, as well as the organist and organ-builder fr. Johannes who contributed to the decoration of the Saint Lawrence's monastery near Buda $[9$, c. 64 , c. 79$]$.

In conclusion: the Paulines belonged to the most popular orders in late medieval Hungary; only the Franciscans had more friaries. Although the order's status and economy changed considerably by the end of the fourteenth century, it 
continued to live in small, sometimes hermitage-like communities, and unlike the mendicant orders, the Hermits of Saint Paul did not support the higher education of the friars. Instead, there were authors of mystic and liturgical literature, as well as artists and skilled craftsmen among the members. The order had a clear concept of the ideal estates it needed, nevertheless, the sustention of the monasteries and the religious also necessitated alms. These came from testators, donators, believers visiting the pilgrimage places run by the Paulines, but also from high ranking persons whom the monks addressed with

\section{References}

1 Documenta Artis Paulinorum I-III. (eds.: Gyéresy B., Hervay F. L.) Budapest (1975-1978).

2 F. Romhányi B., A lelkiek a földiek nélkül nem tarthatók fenn. Pálos gazdálkodás a középkori Magyarországon. Gondolat Kiadó, Budapest (2010).

3 F. Romhányi B., A pálos élet forrásai a középkorvégi Magyarországon. Az Egyetemi Könyvtár Évkönyvei 14-15, 323-330 (2011).

4 F. Romhányi B., Die Wirtschaftstätigkeit der ungarischen Pauliner im Spätmittelalter (15.-16. Jahrhundert). in 'Die Pauliner. Geschichte - Geist - Kultur' (ed.: Sarbak G.) Budapest, 129-199 (2010).

$5 \quad$ F. Romhányi B., Kolostorok és társaskáptalanok a középkori Magyarországon. Pytheas, Budapest (2000).

6 F. Romhányi B., Pálos kolostorok Sopron környékén. Soproni Szemle, 61 (3), 246-254 (2007).

7 Formularium maius ordinis Sancti Pauli primi Heremitae. (eds.: F. Romhányi B., Sarbak G.) Budapest (2013).

8 Guzsik T., A pálos rend építészete a középkori Magyarországon. Budapest (2003).

9 Gyöngyösi Gr., Vitae fratrum Eremitarum Ordinis Sancti Pauli Primi Eremitae. (ed.: Hervay Fr. L.) Budapest (1988).

10 Hungarici monasterii ordinis Sancti Pauli primi heremitae de urbe Roma Instrumenta et priorum registra. (ed. Weinrich L.), RomaBudapest (1999)

11 Kelényi B. O., A Buda melletti Szent Lörinc pálos kolostor történetének első irodalmi forrása (1511). Tanulmányok Budapest Múltjából, 4, 87-110 (1936).

12 Kubinyi A., Magyarország és a pálosok. in 'Decus solitudinis. Pálos évszázadok. (Művelődéstörténeti mühely. Rendtörténeti konferenciák 4/1.) (eds.: Őze S., Sarbak G.) Szent István Társulat, Budapest, 40-56 (2007). supplications or gifts. Although the order had contacts to the towns and cities, its presence there was essentially of economic character; Pauline monasticism has never been an urban feature. The social network of the monks reached from the king to the burghers of the market towns, although the main supporters were the lesser nobility and some aristocratic families. Despite the essential economic differences between the two orders, this characteristic connects them, paradoxically, to the observant Franciscans who were favoured mainly by the same social layers in Hungary.

13 Sarbak G., Das Buch- und Bibliothekswesen der Pauliner im Mittelalter. in 'Beiträge zur Geschichte des Paulinerordens.' (ed.: Elm K., Bauer D. R., Kuhn E. L., Sarbak G., Weinrich L.) Berlin, 41-62 (2000)

14 Sarbak G., Der Paulinerorden an der Schwelle der Neuzeit. in 'Bettelorden in Mitteleuropa: Geschichte, Kunst, Spiritualität.' (eds.: Specht H., Andraschek-Holzer R.), St. Pölten, 316-325 (2008).

15 Sarbak G., Die 'Devotio moderna' in Ungarn. in 'Die Neue Frömmigkeit in Europa im Spätmittelalter’ (eds.: Derwich M., Staub M.), Göttingen, 249-264 (2004).

16 Sarbak G., Mátyás király és a pálosok. in 'Hunyadi Mátyás, a király. Exhibition catalogue.' Budapest, 405-407 (2008).

17 Sarbak G., Miracula Sancti Pauli primi heremitae. Hadnagy Bálint pálos rendi kézikönyve, 1511. Kossuth Egyetemi Kiadó, Debrecen (2003).

18 Sarbak G., Pálosaink írásbelisége. Vigília 66 (2), 112-119 (2001).

19 Sarbak G., Prior General Gregory Gyöngyösi and the History of the Pauline Fathers in the Early $16^{\text {th }}$ Century. in 'Infima aetas Pannonica: Studies in Late Medieval Hungarian History. (eds. P. E. Kovács, K. Szovák.' Budapest, 250-260 (2009).

20 Török J., A magyar pálosrend liturgiájának forrásai, kialakulása és fóbb sajátosságai (1225-1600). Budapest (1977).

21 Urbán M., Pálos zarándokhelyek a késő középkori Magyarországon. Vallástudományi Szemle 5 (1), 63-84 (2009).

22 Zsigmond lengyel herczeg budai számadásai. in 'Magyar Történelmi Tár XXVI.' (ed. Divéky A.), Budapest, 1914.

23 http://mnl.gov.hu/bal menusor/hasznalat/segedletek/adatbazisok.html 